\title{
Risk Factors for latrogenic Vocal Fold Palsy during Thyroid Surgery: A Single Institutional Experience Over 10 Years
}

\author{
Yeong Wook Jeong, Young Seok Han, Hyoung Shin Lee, Sung Won Kim, and Kang Dae Lee \\ Department of Otolaryngology-Head and Neck Surgery, Kosin University College of Medicine, Busan, Korea
}

\section{갑상선 수술 후 의인성 성대 마비의 위험 요인: 10 년간의 단일 기관 경험}

정영욱 · 한영석 · 이형신 · 김성원 · 이강대

고신대학교 의과대학 이비인후과학교실

\footnotetext{
Received June 29, 2020

Revised November 2, 2020

Accepted November 3, 2020

Address for correspondence

Kang Dae Lee, MD, PhD

Department of Otolaryngology-

Head and Neck Surgery,

Kosin University

College of Medicine,

262 Gamcheon-ro, Seo-gu,

Busan 49267, Korea

Tel +82-51-990-6470

Fax +82-51-245-8539

E-mail kdlee59@gmail.com
}

Background and Objectives Recurrent laryngeal nerve (RLN) palsy is a critical complication of thyroid surgery. The aim of this study was to investigate the incidence of iatrogenic temporary or permanent RLN palsy and to determine the surgeon's experience factor for iatrogenic RLN palsy.

Subjects and Method We retrospectively reviewed 3404 patients, who underwent thyroidectomy between 2010 and 2019, to identify the surgeon's experience factor for iatrogenic RLN palsy. Information about patient demographics, surgeon factor, whether or not intraoperative neuromonitoring (IONM) were used, and the postoperative status of RLN were collected. The incidence of RLN injury was analyzed according to the surgeon experience, surgery for thyroid cancer, effect of IONM and the extent of surgery.

Results A total of 4479 RLNs were at risk in 3094 thyroidectomies in this study. There were $34(1.10 \%)$ postoperative vocal cord palsy (VCP) cases after thyroidectomy. All patients with RLN palsy showed a unilateral type. VCP was temporary in $26(0.84 \%)$ cases and permanent in $8(0.26 \%)$ cases. Using the nerve at risk (NAR) method, we found that there were 34 NAR palsy out of the total $(4479)$ NAR $(0.76 \%), 26$ NAR temporary palsy $(0.58 \%)$, and 8 NAR permanent palsy $(0.18 \%)$. The mean recovery time after temporary VCP ranged between $2-180$ days (50.6 days in average). The incidence of permanent RLN injury was higher in surgery conducted by less experienced surgeon $(1.71 \%$ in less experienced vs. $0.05 \%$ in experienced surgeon, odds ratio 35.991, $p<0.001$ ). Application of IONM had no impact on incidence of iatrogenic RLN injury.

Conclusion The present study demonstrated that less experienced surgeon is associated with an increased risk of iatrogenic permanent RLN palsy after thyroidectomy.

Korean J Otorhinolaryngol-Head Neck Surg 2020;63(12):594-602

Key Words Intraoperative neuromonitoring · Recurrent laryngeal nerve injury ·

Thyroidectomy $\cdot$ Vocal cord paralysis.
서 론

갑상선 수술 후 발생할 수 있는 합병증에는 반회후두신경 (recurrent laryngeal nerve, RLN) 손상, 상후두신경(superior laryngeal nerve) 손상, 출혈, 갑상선 기능 저하증, 부갑 상선 기능 저하증, 저칼슘혈증 등이 있다. ${ }^{1)}$ 특히 반회후두신

This is an Open Access article distributed under the terms of the Creative Commons Attribution Non-Commercial License (https://creativecommons.org/licenses/by-nc/4.0) which permits unrestricted non-commercial use, distribution, and reproduction in any medium, provided the original work is properly cited. 
경의 손상은 성대 마비가 발생하여 환자에게 목심(hoarseness) 증상부터 급성 기도 폐쇄(acute airway obstruction)까 지 다양한 불편함을 야기할 수 있으며, 양측 성대 마비가 발 생했을 경우 기관 절개술이 필요할 수 있다. ${ }^{2,3)}$ 반회후두신경 의 손상은 일시적인 손상과 영구적인 손상으로 나눌 수 있으 며, 일시적인 경우는 약 3 8\%의 빈도를 보이고 영구적인 경우 는 약 $0.3 \sim 3 \%$ 의 빈도로 보고된다. ${ }^{2)}$ 수술 중 반회후두신경 손 상의 원인으로는 긴장(traction), 압박(compression), 열 손상 (thermal injury), 절단(transection) 등이 있다.1.3) 갑상선 수술 하는 의사들은 수술 중 반회후두신경의 손상을 줄이기 위해 노력하고 있으며 신경을 보존하기 위한 다양한 기술이 연구되 고 있지만, 대부분 여전히 술자의 경험에 많이 의존하여 수술 하고 있다. 최근에는 객관적인 근거를 기반으로 안전하게 수 술하기 위하여 갑상선 수술 중 신경모니터링(intraoperative neuromonitoring, IONM)을 사용하여 반회후두신경의 주 행을 예측 및 확인하고, 이를 안전하게 보존하여 수술 후 성 대 기능을 보존하려는 노력을 하고 있다. IONM의 사용이 반 회후두신경의 손상을 줄인다는 주장은 초기에는 논란이 있 었지만, ${ }^{3)}$ 최근의 연구에서는 IONM을 사용하는 것이 반회후 두신경을 발견하는 데 효과적인 도움을 주고 있으며, 결과적 으로 의인성 반회후두신경 손상을 낮추는 것으로 보고하고 있다.

술자는 갑상선 수술 예정인 환자에게 수술 과정과 발생 가 능한 합병증, 특히 수술 후 반회후두신경의 손상 가능성에 대 해 정확히 설명해야 한다. 따라서, 술자는 신경 손상 가능성 이 높은 경우에 신경 마비에 영향을 미치는 위험 인자를 숙지 하고 있어야 한다. 이에 저자들은 2010년 1월 2019년 11월까 지 고신대학교 복음병원 이비인후과에서 시행한 갑상선 절제 술 후 발생한 의인성 성대 마비의 발생률과 위험인자를 분석 하였으며, 성대마비의 위험인자와 IONM의 관련성을 후향적 으로 분석하여, 갑상선 수술시 의인성 반회후두신경 손상의 발생을 예방하기 위한 도움을 얻고자 본 연구를 시행하였다.

\section{대상 및 방법}

\section{환자군}

후향적으로 환자의 의무기록을 조사하였으며, 고신대학교 복음병원 윤리심사위원회(2020-03-047)로부터 승인받았다. 2010년 1월 2019년 11월까지 고신대학교 복음병원 이비인후 과에서 갑상선 수술을 받은 모든 환자를 대상으로 분석하였 다. 암종이 신경을 침범한 경우(RLN invasion), 갑상선 암종이 신경을 침범하지 않았더라도 수술 전에 이미 성대 마비가 있 었던 경우, 협부 절제술(isthmusectomy), 동일 부위에 재수술
을 받은 경우(revision)는 연구 대상에서 제외하였다.

수술의 방법은 갑상선 전절제술, 갑상선 일측엽 절제술로 나눴으며, 중심 구획 림프절 곽청술은 예방적 목적에서 악성 으로 진단된 모든 수술에 함께 시행되었다. 만약 측경부에 임 상적으로 명확한 전이 림프절이 발견되었을 경우에는 측경부 림프절 곽청술을 함께 시행하였다.

\section{반회후두신경 손상}

모든 환자는 수술 전 질병의 범위를 정확하게 평가하기 위 해서 갑상선 초음파, 경부 컴퓨터단층촬영, 갑상선 및 부갑상 선 호르몬 검사를 포함한 혈액검사, 음성 검사를 시행하였 다. 수술 전날 성대 움직임을 검사하기 위한 후두내시경 $(1 \mathrm{a}-$ ryngoscopy)을 시행하였으며, 수술 직후 회복실에서 모든 환 자에게 휴대용 굴곡내시경(portable fiberscopy)을 통해 성대 마비 여부를 평가하였고, 수술 1 일 후 후두내시경으로 한번 더 평가하였다. 수술 후 회복실에서 성대 마비가 의심되는 환 자는, 입원 중 후두내시경을 수술 1 일 후, 3 일 후에 시행하였 다. 모든 환자는 퇴원 후 1 주일, 1 개월, 3 개월 시기에 외래를 통 해 경과 관찰하였고, 각 방문 시 후두내시경 검사와 음성 검 사를 시행하였다. 수술 3 개월 후에도 지속적으로 6 개월 간격 으로 경과 관찰하였다.

반회후두신경의 마비는 후두내시경 검사 결과 성대의 움직 임이 건측과 비교하여 감소하거나 움직임이 없는 경우로 진단 하였으며, 6 개월 이내에 정상으로 회복되는 경우를 일시적인 마비로 정의하였다. 또한 수술 중 신경의 절단을 포함한 직접 적 손상이 발생하였거나, 6 개월 이상 성대 마비가 지속될 경 우 영구적인 마비로 분류하였다. 일시적인 마비의 경우 성대 마비가 발생한 시점부터, 성대의 움직임이 회복되고 환자의 주관적 증상이 사라지는 시점까지의 회복 기간을 함께 조사 하였다.

모든 수술은 이비인후과 두경부외과 전문의가 시행하였으 며, 1 년에 약 100 건 이상의 갑상선 절제술을 시행하는 경우 숙 련된(experienced) 술자로 분류하였으며, 1년에 약 100건 미 만의 갑상선 절제술을 시행하는 경우를 덜 숙련된(less-experienced) 술자로 분류하였다. ${ }^{2)}$ 본 연구에서는 연구기간동안 3 명의 숙련된 술자, 6 명의 덜 숙련된 술자가 갑상선 수술을 시행하였으며, 6명의 덜 숙련된 술자는 모두 전임의(fellow) 였다.

\section{수술 중 신경모니터링}

2000 2015년까지 갑상선 수술에서 신경자극기(VARI-STIM III nerve stimulator, Medtronic Inc, Jacksonville, FL, USA) 를 사용하여 반회후두신경을 안전하게 보존하기 위해 노력하 
였다. 반회후두신경이 노출된 후 1 2 $\mathrm{mA}$ 의 세기로 신경의 가 장 근위부(proximal part)를 자극하였으며, 술자의 검지손가 락으로 후두의 후윤상피열근(posterior cricoarytenoid muscle)의 수축 여부를 확인하였다. 수술 중 반회후두신경의 모 니터링 시스템[NIM Response 3.0(Medtronic Xomed, Jacksonville, Florida, USA)]은 2015년 1월에 도입되었으며, 한 국의 보험 기준의 적응증에 맞춰 표준화된 IONM 가이드라 인에 따라 시행하였다. ${ }^{5)} \mathrm{IONM}$ 연구의 발전에 따라 2019년 2월부터는 앞서 언급한 보험 기준에 해당하지 않는 환자의 경우에도 바늘형 전극(subdermal needle electrode), ${ }^{6}$ 피부 부착형 전극(skin surface electrode) ${ }^{7)}$ 을 사용하여 모든 갑 상선 수술에 IONM을 사용하였다.

\section{임상병리학적 요인}

기존 연구에 따르면 수술 후 반회후두신경 손상에 영향을 미치는 요인으로 술자의 경험, 갑상선 질환의 종류(양성 또는 악성), IONM의 사용 여부, 수술의 범위(갑상선 전절제술 또는 엽절제술) 등이 있다. ${ }^{3,89}$ 본 연구에서는 후향적 연구의 한계 로 인해 주로 술자의 경험과 IONM의 사용 여부에 대해 중점 적으로 평가하였다. 또한 성대마비가 발생한 환자들의 체질량 지수(body mass index, BMI), AJCC 8판에 근거한 병기, 종 양의 크기 및 위치, 갑상선염 여부, 추가 치료 방법에 대해 조 사하였다.

\section{통계 분석}

본 연구에서 조사한 항목들은 모두 명목 변수들이며 각 변 수의 빈도에 대한 상관관계를 조사하기 위해, 기대 빈도가 5 미만일 경우에는 피셔의 정확 검정(Fisher's exact test)을 사 용하였으며, 기대 빈도가 5 를 초과한 경우에는 피어슨 카이제 곱 검정(Pearson's chi-square test)을 사용하였다. 또한 로지 스틱 회귀 분석(logistic regression test)을 사용하여 성대 마 비에 영향을 미치는 위험인자들을 조사하였다. 모든 통계는 $p$ 값이 0.05 미만일 경우 통계적으로 유의한 위험인자라고 판 단하였다. 분석은 SPSS(version 25.0, IBM Corp., Armonk, NY, USA)를 이용하여 시행하였다.

\section{결 과}

2010년 1월 2019년 11월까지 고신대학교 복음병원 이비인 후과에서 시행한 갑상선 수술은 총 3404예이며, 이중 갑상선 협부 절제술 110예는 제외하였다. 또한 수술 중에 갑상선 암 종이 반회후두신경을 침범한 경우 120예도 제외하였으며 갑 상선 암종이 신경을 침범하지 않았더라도 수술 전에 이미 성
대 마비가 있었던 7예 또한 연구 대상에서 제외하였다. 그리 고 동일 부위에 재수술을 받은 경우 73예를 제외하여, 최종적 으로 3094예를 대상으로 연구를 시행하였다(Fig. 1).

전체 환자의 평균 나이는 47.91(10 82)세였으며, 남성은 594 명(19.2\%), 여성은 2500명(80.8\%)이었다. 대상 환자들 중 에서 총 34 명이 수술 중 의인성 반회후두신경 마비가 발생 (1.10\%)하였으며, 반회후두신경의 일시적인 마비는 총 26명 (0.84\%)이었고, 영구적인 마비는 8 명 $(0.26 \%)$ 이었다. 수술 후 성대 마비가 발생한 34 명의 환자들 모두 일측(unilateral)의 성대 마비였으며, 일시적인 마비가 발생한 26예의 경우 평균 회복기간이 50.6(7 180)일이었다.

반회후두신경 손상은 nerve at risk(NAR) 개념을 사용하 여 평가하였다. 갑상선 전절제술은 양측 신경이 모두 노출되 기 때문에 2 로 계산하였고, 일측엽 절제술은 일측의 신경이 노출되므로 1 로 계산하였다. ${ }^{1)}$ 총 3094 명의 환자들의 NAR은 4479였다. NAR 방식으로 계산하였을 때 전체 성대 마비의 빈 도는 $0.76 \%$ (34/4479 NAR)였으며, 일시적인 마비는 0.58\% (26/4479 NAR), 영구적인 마비는 0.18\%(8/4479 NAR)로 발 생하였다(Table 1).

각각의 요인들이 갑상선 수술 후 반회후두신경의 마비에 영향을 미치는 정도를 분석한 결과는 Table 2에 요약하였다. 숙련된 술자의 경우 $0.68 \%(28 / 4129 \mathrm{NAR})$ 에서 성대 마비가 발생하였으며, 덜 숙련된 술자의 경우 $1.71 \%(6 / 350 \mathrm{NAR})$ 에서

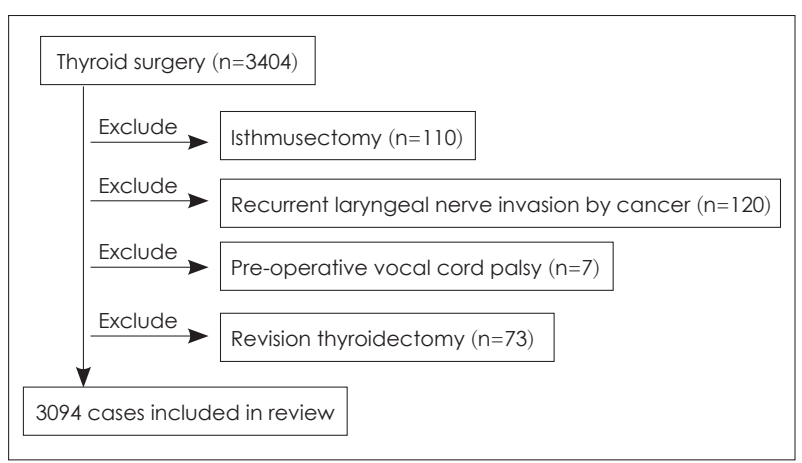

Fig. 1. Flow chart of study based on the inclusion/exclusion criteria.

Table 1. Incidence of iatrogenic RLN palsy

\begin{tabular}{lrc}
\hline & $\mathrm{n}$ & Ratio (\%) \\
\hline RLN palsy (person) ( $\mathrm{n}=3094)$ & 26 & 0.8 \\
Temporary & 8 & 0.26 \\
Permanent & 34 & 1.10 \\
Total & & \\
RLN palsy (nerve at risk) $(\mathrm{n}=4479)$ & 26 & 0.58 \\
Temporary & 8 & 0.18 \\
Permanent & 34 & 0.76 \\
Total & & \\
\hline
\end{tabular}

RLN: recurrent laryngeal nerve 
latrogenic Vocal Fold Palsy I Jeong YW, et al.

Table 2. Total numbers and risk of factors for RLN injury after thyroid surgery

\begin{tabular}{|c|c|c|c|c|c|c|c|}
\hline & \multirow{2}{*}{$\begin{array}{l}\text { Nerve } \\
\text { at risk }\end{array}$} & \multicolumn{3}{|c|}{ Temporary RLN injury } & \multicolumn{3}{|c|}{ Permanent RLN injury } \\
\hline & & n (ratio, \%) & $p$ value & OR $(95 \% \mathrm{Cl})$ & n (ratio, \%) & $p$ value & OR $(95 \% \mathrm{Cl})$ \\
\hline Surgeon & & & 0.260 & $1.006(1.004-1.009)$ & & $<0.001$ & $35.991(7.237-178.995)$ \\
\hline Experienced & 4129 & $26(0.63)$ & & & $2(0.05)$ & & \\
\hline Less-experienced & 350 & $0(0)$ & & & $6(1.71)$ & & \\
\hline Pathology & & & 0.627 & $0.994(0.992-0.996)$ & & 1.000 & $0.998(0.997-0.999)$ \\
\hline Benign & 193 & $0(0)$ & & & $0(0)$ & & \\
\hline Malignant & 4286 & $26(0.61)$ & & & $8(0.19)$ & & \\
\hline \multicolumn{2}{|c|}{ Intraoperative neuromonitoring } & & 0.379 & $0.709(0.328-1.532)$ & & 0.482 & $2.133(0.430-10.581)$ \\
\hline Yes & 1860 & $13(0.70)$ & & & $2(0.11)$ & & \\
\hline No & 2619 & $13(0.50)$ & & & $6(0.23)$ & & \\
\hline Extent of surgery & & & 0.461 & $1.367(0.593-3.151)$ & & 0.006 & $0.086(0.011-0.702)$ \\
\hline Total thyroidectomy & 2788 & $18(0.65)$ & & & $1(0.04)$ & & \\
\hline Lobectomy & 1691 & $8(0.47)$ & & & $7(0.41)$ & & \\
\hline
\end{tabular}

RLN: recurrent laryngeal nerve, OR: odds ratio, $\mathrm{Cl}$ : confidence interval

성대 마비가 발생하였다. 수술 후 성대 마비가 발생한 모든 경 우의 최종 조직검사 결과 악성으로 진단(0.80\%, 34/4286 NAR) 되었으며, IONM의 도입 전과 후를 비교하였을 때 도입 전은 0.73\%(19/2619 NAR), 도입 후는 0.81\%(15/1860 NAR)에서 발생하였다. 수술의 범위로 비교했을 때는 갑상선 전절제술을 받은 경우 0.69\%(19/2788 NAR), 갑상선 엽절제술을 받은 경 우 0.88\%(15/1691 NAR)로 발생하였다.

일시적인 성대 마비와 영구적인 성대 마비를 나누어 각각 분석하였을 때, 일시적인 성대 마비의 경우 숙련된 술자에서 0.63\%(26/4129 NAR), 덜 숙련된 술자에서 0\%(0/350 NAR) 로 발생하였다[odds ratio(OR): 1.006; 95\% confidence interval(CI): 1.004 1.009, $p=0.260]$. 모두 악성으로 진단(0.61\%, 26/4286 NAR)되었으며(OR: 0.994; 95\% CI: 0.992 0.996, $p=0.627)$ IONM 도입 전에는 $0.50 \%(13 / 2619 \mathrm{NAR})$, 도입 후 에는 0.70\%(13/1860 NAR)이었다(OR: 0.709; 95\% CI: $0.328 \sim 1.532, p=0.379)$. 갑상선 전절제술을 받은 경우 $0.65 \%$ (18/2788 NAR), 엽절제술을 받은 경우 $0.47 \%$ (8/1691 NAR) 이었다(OR: $1.367 ; 95 \%$ CI: 0.593 3.151, $p=0.461)$.

영구적인 성대 마비의 경우 숙련된 술자에서 $0.05 \%(2 / 4129$ $\mathrm{NAR}$, 덜 숙련된 술자에서 $1.71 \%(6 / 350 \mathrm{NAR}$ 로 발생하였다 (OR: 35.991; 95\% CI: 7.237 178.995, $p<0.001$ ) 모두 악성으로 진단(0.19\%, 8/4286 NAR)되었으며(OR: 0.998; 95\% CI: 0.997 $0.999, p=1.000), \mathrm{IONM}$ 도입 전에는 $0.23 \%(6 / 2619 \mathrm{NAR})$, 도 입 후에는 $0.11 \%(2 / 1860 \mathrm{NAR})$ 이었다(OR: $2.133 ; 95 \% \mathrm{CI}$ : $0.430 ~ 10.581, p=0.482$ ). 갑상선 전절제술을 받은 경우 $0.04 \%$ (1/2788 NAR), 엽절제술을 받은 경우 $0.41 \%(7 / 1691 \mathrm{NAR})$ 이 었다(OR: 0.086; 95\% CI: 0.011 0.702, $p=0.006$ ).

또한 신경 마비가 발생한 34명의 임상병리학적 정보는 $\mathrm{Ta}-$ ble 3에 요약되어 있다. 환자들의 체질량지수 평균은 24.1이었 으며, 정상 범위(18.5 24.9)인 경우는 21명, 과체중 범위(25.0 29.9)는 11명, 비만 범위(30.0 이상)인 경우는 2명이었다. 모든 경우 최종 조직검사에서 갑상선 유두암(papillary thyroid cancer)으로 진단되었으며, AJCC 8판에 근거하여 병기를 조사하 였을 때, Tla 13명, T1b 6명, T3a 1명, T3b 14명이었으며, N0 20명, N1a 9명, N1b 5명이었다. 종양의 위치는 갑상선 전방 피 막(anterior thyroid capsule)에 인접한 경우 11명, 갑상선 피 막 내에 존재하는 경우(intracapsular type) 13 명, 갑상선 후 방 피막(posterior thyroid capsule)에 인접한 경우 10명이었으 며, 갑상선염(thyroiditis)이 동반되어 있는 경우는 10명이었다. 수술 후 일시적인 신경 마비가 있었던 26명의 환자들은 외래 에서 경과 관찰하던 중 모두 후두내시경을 통해 성대의 움직 임이 회복된 것을 확인하였다. 영구적인 신경 마비가 있었던 8 명의 환자들 중에서 6 명은 신경이 부분적 또는 완전 절단되 어 발생한 손상으로 신경봉합술(neurorrhaphy)을 시행하였 으며, 나머지 2 명의 환자들은 신경의 구조적 손상은 없었으나 수술 후 신경 마비가 영구적으로 발생한 경우로 환자의 불편 함이 경미하여 추가적인 처치 없이 추적 관찰하고 있다.

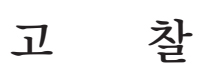

많은 연구에서 갑상선 수술 후 발생할 수 있는 합병증에 대 해 강조하였으며, 특히 갑상선 수술 후 발생하는 반회후두신 경의 마비에 초점을 맞추고 있다. ${ }^{2.8}$ 갑상선 수술 후 반회후두 신경 손상으로 인한 성대 마비는 일시적 및 영구적으로 발생 할 수 있으며, 일시적인 경우는 약 3.0 8.0\%, 영구적인 경우 는 약 0.3 3.0\%의 빈도로 보고된다. ${ }^{2}$ 저자들의 경우 약 10 년 


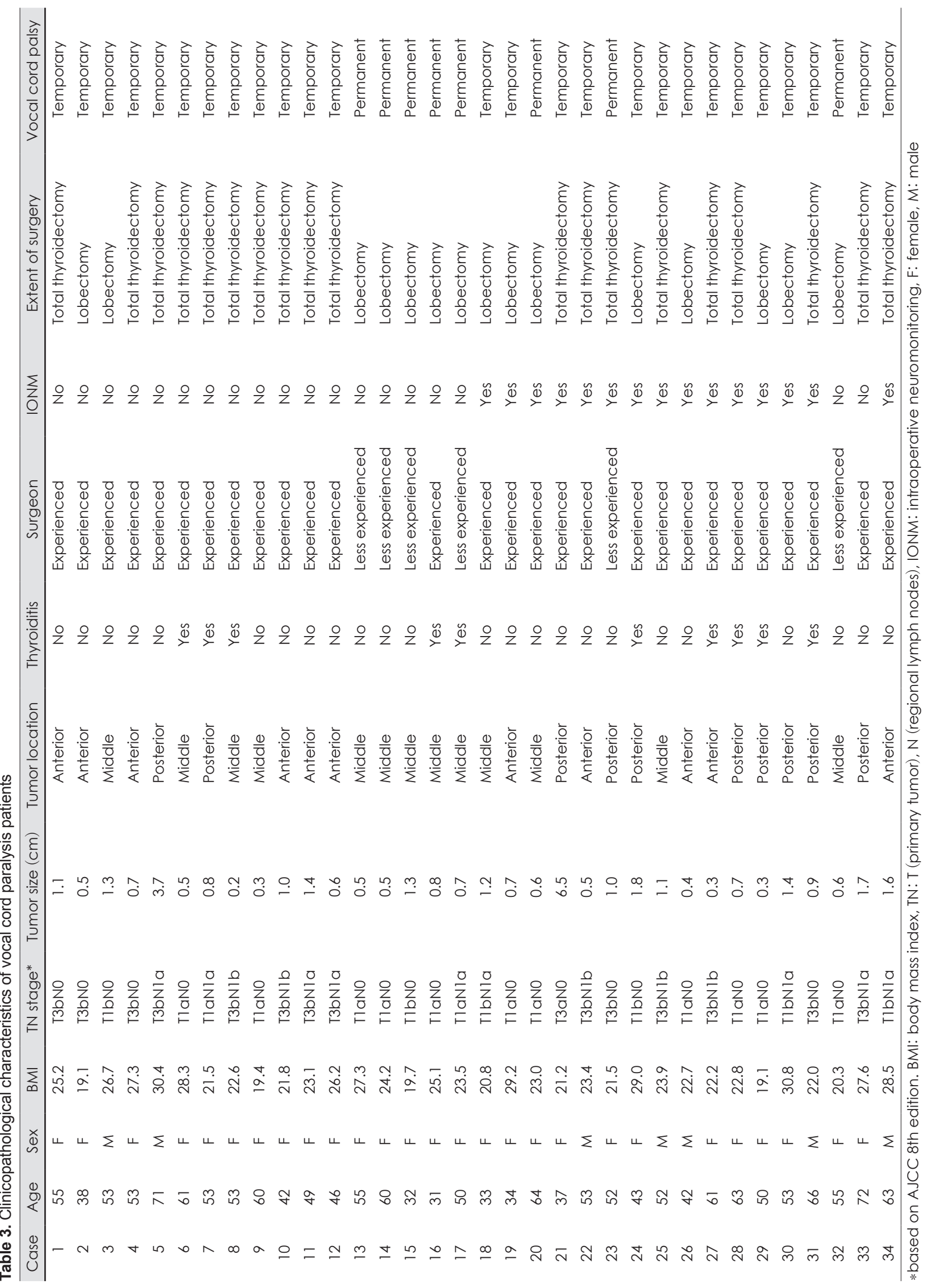


간의 경험을 고찰하였을 때 갑상선 수술 후 일시적인 성대 마비는 $0.84 \%$, 영구적인 성대 마비는 $0.26 \%$ 로서, 전체 성대 마비는 $1.10 \%$ 의 낮은 빈도로 발생하였다. 특히 NAR 개념을 사용하여 빈도를 조사하였을 때는 전체 빈도가 $0.76 \%$ 로 매 우 낮은 발생률을 보였다. 일시적인 성대 마비의 경우 회복되 는 기간을 함께 조사하였는데, 한 연구에 의하면 일시적인 신경 마비의 경우 평균적으로 4 6주 사이에 완전한 회복을 보였으며, 12 개월까지 회복을 지켜볼 수 있다고 보고했다. ${ }^{10}$ 본 연구의 결과에 의하면 일시적인 성대 마비의 경우 평균적 으로 발생 50.6(7 180)일 이후 성대의 기능이 회복되었다. 따 라서, 갑상선 수술 후 성대의 마비가 발생한 경우 50일 정도 는 기다려 볼 수 있으며, 성대 마비가 발생한지 180일 이후에 성대 기능이 회복된 경우도 있었으므로 최대 6 개월까지 회 복을 기다려볼 수 있을 것으로 사료된다.

한 연구에 의하면 수술 후 후두내시경을 항상 시행하는 경 우, 시행하지 않는 경우보다 수술 후 성대 마비의 빈도가 높게 나왔다고 보고하였다. ${ }^{11)}$ 이는 수술 후 후두내시경을 통해 정 확한 성대 움직임을 평가하지 않는 경우, 실제 성대 마비를 발 견하지 못하여 과소평가(underestimated) 된다는 것을 의미 한다. 본 연구에서는 갑상선 수술 전 후두내시경을 통해 성대 움직임을 확인하였으며, 수술 직후에도 휴대용 굴곡내시경을 통해 모든 환자의 성대 움직임을 확인하였다. IONM 시스템 의 이상으로 신경 손상이 위양성으로 나올 수 있기 때문에, 수 술 직후 회복실에서 성대 움직임을 정확하게 평가하는 것이 중요하다. 또한, 회복실에서 양측 성대 마비가 관찰된다면 급 성 기도 폐쇄가 발생할 수 있으며, 이 같은 경우에는 응급 기 관절개술이 필요할 수 있으므로 수술 직후 평가하는 것이 매 우 중요하다. 하지만, 마취에서 회복된 시간이 짧을 경우에는 통증 및 기도삽관 제거(extubation) 후 불편감 등으로 환자의 검사 순응도가 떨어져서 정확한 평가가 어려울 수 있다. ${ }^{12)}$ 따 라서, 입원 중 한번 더 후두내시경을 시행하여 성대를 확인하 는 것이 정확한 성대 마비를 평가하는 데 필요할 것으로 사료 되어, 본과에서는 수술 1 일 후 한번 더 후두내시경을 추적 관 찰 하였다. 수술 전날, 수술 직후, 수술 다음날 성대의 움직임 을 최소 3 회 평가하여 성대 마비를 놓치지 않는 것이 중요하 며, 성대 마비가 발견되는 즉시 적절한 조치를 취할 수 있으므 로 후두내시경 검사는 매우 중요하다고 볼 수 있다.

술자의 숙련도의 관점에서 보면, 한 연구에서는 1 년에 100 개 이상의 갑상선 수술을 하는 술자의 경우 수술 후 합병증의 빈 도를 현격하게 감소시킨다고 보고했다. ${ }^{2)}$ 하지만 경험이 많은 능숙한 술자는 비교적 복잡한 악성 종양 절제술 또는 재수술 (re-operative surgery)을 더 많이 집도하게 되므로 정확한 평 가는 어렵다. 결과에서 통계적으로 유의하게 숙련된 술자의 경
우에 영구적인 성대 마비의 빈도가 낮게 나온 것으로 볼 때, 갑상선 수술에서 술자의 경험이 점점 쌓여갈수록 수술 후 성 대 마비가 더 적게 발생한다는 것으로 판단할 수 있다. 따라서, 모든 술자는 갑상선 수술의 해부학적 지식을 풍부하게 습득하 여야 하며, 신경 주위를 세밀하게 수술하는 경우에는 더욱더 심혈을 기울여야 하고, 출혈이 예상되는 부위에서는 미리 혈관 을 결찰하여 출혈을 예방해야 한다.,13) 특히 하부갑상선동맥 (inferior thyroid artery)은 반회후두신경과 복잡한 해부학적 인 구조를 형성하고 있을 수 있기 때문에, 이점을 미리 인지하 고 신경을 혈관으로부터 안전하게 박리하여 수술을 진행하여 야 한다. ${ }^{14)}$ 하지만, 본 연구에서 분석한 두 군에서 갑상선 종양 의 크기 및 위치, 갑상선염 여부, BMI 등이 포함되지 않았기 때문에, 술자의 숙련도의 관점을 정확하게 비교할 수 없다는 것이 한계점이다.

우리나라에서는 IONM을 통한 객관적인 근거를 기반으로 신경을 안전하게 보존하려는 노력은 점점 증가하는 추세이지 만, IONM의 사용이 반회후두신경의 손상을 줄인다는 주장 은 논란이 있으며, ${ }^{3)}$ 여전히 술자의 경험에 의존한 수술이 더 많이 시행되고 있다. 반회후두신경의 주행에 해부학적으로 변 이가 있을 수 있으므로, 갑상선 수술 중 신경 손상을 예방하기 위해 '수술 중 환측의 반회후두신경을 필수로 확인하고 주행 을 인지하는 것'이 필요하다는 개념은 대부분의 술자가 동의 하고 있다. ${ }^{15-17)}$ 따라서 최근에는 경험에만 의존하는 것이 아니 라 갑상선 수술 중 IONM을 사용하여 신경을 보존하고자 노 력하고 있다. 2011년에 시행된 메타분석 연구에 따르면, IONM 을 사용하여 반회후두신경을 보존하였던 경우가 모니터링을 사용하지 않은 경우보다 수술 후 성대 마비 발생을 통계적으 로 유의미하게 낮추지 않는다고 보고하였다. ${ }^{11)}$ 하지만, 갑상선 수술 중 IONM을 사용하는 것이 편하다고 생각하는 술자는 꼭 사용하는 것을 추천하고 있다. ${ }^{11)}$ 또한, IONM의 비용 대비 효율이 높다는 연구는 없으나, 신경의 주행에 변이가 있는 경 우, 갑상선 전절제술 및 중심 구획 림프절 곽청술을 시행하는 경우는 IONM을 사용하는 것을 권고하였다. ${ }^{18)}$ 그리고 2012년 에 보고된 메타분석 연구에서는 갑상선 수술 후 일시적인 성 대 마비의 경우에는 IONM의 사용이 통계적으로 유의하게 발 생률을 낮췄다고 하였으나, 영구적인 성대 마비의 경우에는 통계적인 유의성이 없다고 주장하였다. ${ }^{3)}$ 하지만 IONM을 통 해서 신경의 긴장으로 인한 손상을 즉각적으로 발견할 경우, 긴장을 해소하면 약 20분 이내에 신경이 회복될 수 있으므로 수술 후 일시적인 성대 마비를 예방할 수 있다는 점에서 그 효 용성이 충분하다고 볼 수 있다. ${ }^{19}$ 또한 최근의 연구에서는 반 회후두신경을 확인하고, 이를 안전하게 보존하여 손상을 예 방하는 데 IONM이 매우 중요하다고 보고하고 있으며, ${ }^{4}$ 재수 
술을 시행할 때 IONM을 사용하였을 경우와 사용하지 않았 을 경우, 수술 후 반회후두신경 마비의 발생률에 유의미한 결 과는 없었으나, 여전히 많은 어려운 수술에서 IONM이 신경 을 확실하게 확인하는 데 매우 중요하다고 주장하였다. ${ }^{20)}$

본과에서는 2000년부터 갑상선 수술에서 신경자극기를 지 속적으로 사용하여 반회후두신경의 기능을 평가하였으며, 신 경의 손상을 줄이기 위해 노력하였다. 신경자극기를 사용하여 $\mathrm{IONM}$ 의 개념에 익숙해진 상태에서 2015년 IONM 시스템이 도입되었다. 2015년부터는 한국의 보험 기준의 적응증에 해당 하는 경우, IONM 시스템을 표준화된 가이드라인에 맞춰 사 용하였다. 보험 기준에 해당하지 않는 경우에는 IONM 시스템 을 사용하는 것에 한계가 있었으나, 연구의 발전에 따라 2019 년 2월부터는 보험 기준에 해당하지 않는 환자의 경우에도 바 늘형 전극, 피부 부착형 전극을 사용하여 갑상선 협부 절제술 을 제외한 모든 갑상선 수술에 IONM을 사용할 수 있게 되었 다. 본 연구에서는 IONM의 사용과 신경 마비의 발생이 통계 적으로 의미 있는 관계가 있다고 나오지 않았다. 또한, 숙련된 술자와 덜 숙련된 술자의 두 그룹으로 나눠서 IONM과 수술 후 성대 마비 발생을 분석하였을 때, 숙련된 술자의 그룹에서 는 IONM을 사용한 경우 $0.77 \%(14 / 1820 \mathrm{NAR})$, 사용하지 않 은 경우 0.61\%(14/2309 NAR)로 성대 마비가 발생하였다. 덜 숙련된 술자의 그룹에서는 IONM을 사용한 경우 2.5\%(1/40 NAR), 사용하지 않은 경우 $1.61 \%(5 / 310 \mathrm{NAR})$ 였으며, 두 그 룹 모두에서 통계적으로 의미는 없었다(Table 4). 본 연구에서 유의미한 결과가 나오지 않은 이유는, 첫째로 본과에서는 신 경모니터링을 하지 않은 환자에서도 신경자극기를 사용하여 갑상선 수술에서 반회후두신경을 확인하는 데 많이 사용하 여 왔기 때문이다. 둘째로 본과에서 1998 2008년까지 시행 한 갑상선 수술 후 성대마비 발생률이 전체 $2.18 \%$, 일시적인 성대마비 $1.49 \%$, 영구적인 성대마비 $0.69 \%$ 로 매우 낮았다. ${ }^{13)}$ 따라서 과거 수술로부터 지속적으로 축적된 경험을 통해 신 경 손상의 빈도가 이미 최소화된 상태였기 때문이다. 하지만, 앞서 언급한 한계점처럼 두 군의 자세한 정보(종양의 크기 및

Table 4. Comparison of RLN injury according to IONM application, stratified as either an experienced or less experienced surgeon

\begin{tabular}{lccc}
\hline \multicolumn{1}{c}{ IONM } & $\begin{array}{c}\text { RLN injury } \\
\text { (ratio, \%) }\end{array}$ & $\begin{array}{c}\mathrm{p} \\
\text { value }\end{array}$ & $\begin{array}{c}\text { Odds ratio } \\
(95 \% \mathrm{Cl})\end{array}$ \\
\hline $\begin{array}{l}\text { Experienced surgeon } \\
\text { Yes }(\mathrm{n}=1820)\end{array}$ & $14(0.77)$ & 0.527 & $0.787(0.374-1.655)$ \\
No $(\mathrm{n}=2309)$ & $14(0.61)$ & & \\
Less-experienced surgeon & 0.520 & $0.639(0.073-5.615)$ \\
Yes $(\mathrm{n}=40)$ & $1(2.5)$ & & \\
No $(\mathrm{n}=310)$ & $5(1.61)$ & &
\end{tabular}

IONM: intraoperative neuromonitoring, RLN: recurrent laryngeal nerve, Cl: confidence interval
위치, 갑상선염 여부, $\mathrm{BMI}$ 등)가 포함되지 않았기 때문에, 추 후 더 많은 연구를 통해 IONM의 효용성이 더 명확하게 밝혀 질 것으로 생각된다.

본과에서는 재수술을 받는 경우에 IONM을 필수적으로 사용하고 있으며, 신경의 위치를 미리 확인하고 안전하게 수 술하는 데 큰 도움을 받고 있다. 이전 연구들에서 갑상선 수 술 과거력이 있는 환자들이 동일 부위에 재수술을 받을 경우 수술 후 반회후두신경 마비 발생이 의미 있게 올라간다는 보 고가 있었다. ${ }^{89}$ 재수술의 경우 이전 수술로 인해 반흔 조직들 이 발생하여 조직이 단단해져 있거나, 정상적인 해부학적 구조 가 달라져 있을 가능성이 높다. 이 같은 경우 수술 중 신경을 확인하는 것이 어려우며, 신경을 확인하더라도 박리하는 과정 에서 긴장 및 열 손상으로 인해 신경 손상 발생률이 일차수술 보다 2 12\%까지 더 높게 발생할 수 있다. ${ }^{13)}$ 일반적으로 갑상 선의 악성 종양은 병이 진행될수록 주위의 연조직, 근육, 혈관, 신경 등을 침범하게 된다. 종양의 크기가 작더라도 악성 종양 의 위치가 주위의 근육과 신경과 인접하거나 침범한 경우에 는 신경을 안전하게 박리하고 보존하는 것이 어려울 수 있으 므로, 양성 종양의 수술보다 악성 종양의 수술 시 갑상선 수 술 후 반회후두신경의 마비 가능성이 높아진다는 보고가 있 었다. ${ }^{2}$ 본 연구에서는 갑상선 수술 과정에서 발생할 수 있는 의인성 신경 마비를 알아보기 위하여 갑상선의 악성 종양이 반회후두신경을 침범한 경우에는 수술 전후 성대 마비의 여 부와 관계없이 대상에서 제외하였고, 결과에서는 갑상선 종양 의 악성 여부와 수술 후 성대 마비의 발생은 통계적으로 연관 성이 없는 것으로 나왔다. 그리고 수술의 범위와 수술 후 성대 마비의 발생과의 연관성도 함께 분석하였는데, 일반적으로 갑 상선 전절제술 이상 수술의 범위가 넓은 수술을 받은 경우에 는 갑상선 엽절제술의 경우보다 수술 후 성대 마비 등의 합병 증의 빈도가 높은 것으로 알려져 있다. ${ }^{9)}$ 수술의 범위가 넓을 수록 범위가 적은 환자보다 질병의 중증도가 더 높은 경우가 많으며, 그만큼 수술의 난이도가 어려울 가능성이 높다. 하지 만, 결과에서 수술의 범위와 성대 마비의 발생률 사이에는 통 계학적으로는 의미가 없는 것으로 확인되었다.

본 연구에서는 성대 마비가 발생한 34예에서 체질량 지수, 종양의 크기, 종양의 위치, 갑상선염의 여부를 함께 조사하였 다. 환자의 체질량 지수가 클수록 갑상선 주위 지방조직이 많으 며, 갑상선을 신경으로부터 박리하는 과정에서 정확한 해부 학적 구조를 확인하는 데 방해가 될 수 있다. 종양의 크기와 위치에 따라서도 수술의 난이도가 달라질 수 있다. 갑상선 종 양이 갑상선 윗부분에 존재하더라도 종양의 크기가 크다면 신경의 박리에 어려움이 있을 수 있으며, 종양이 갑상선 중간 부분에 존재하며 크기가 작다고 하더라도 신경과 인접한 위 
치에 존재한다면 수술이 어려울 것으로 예상된다. 또한, 갑상 선 염증이 함께 있는 환자들의 갑상선은 정상에 비해 크기가 크며, 혈관이 더 풍부하게 발달되어 있다. 따라서 수술 전 초 음파 검사에서 갑상선 염증이 의심되는 환자들은 갑상선 염증 이 없는 환자들의 수술보다 더 어려울 수 있다. 하지만 본 연 구에서 앞서 언급한 요인들을 성대 마비가 발생하지 않은 대 조군과 비교하지 않았기에 정확한 통계학적인 의미를 알 수 없는 한계가 있다. 추후 연구에서는 대조군을 설정하여 각각 의 요인이 성대 마비의 발생에 관여하는 위험인자의 여부를 확인해야 할 것으로 사료된다.

갑상선 수술 중 반회후두신경의 손상을 줄이는 데 가장 중 요한 것은 신경 손상의 가능성이 높은 상황을 충분히 미리 인 지하여 발생하지 않도록 예방하는 것이다. ${ }^{17)}$ 본 연구에서 고 려하였던 요인들 중에서 술자의 숙련도가 높을수록 영구적인 신경 손상의 가능성이 낮아진 것 외에 다른 변수들에서는 모 두 통계적으로 의미가 없는 것으로 나왔다. 본 연구에 몇 가지 한계점이 존재하는데, 첫째로 전체 성대 마비 발생률이 $1 \%$ 미 만으로 매우 낮으므로 정확한 관련성을 평가하기 어렵다는 것 이다. 둘째로 수술 과정에서 긴장성 손상으로 수분에서 수십 분의 신경 마비가 발생한 후 신경의 긴장을 풀었을 때(release) 마비가 회복된 경우도 있었으나, 이는 의무 기록에 성대 마비 로 기록하지 않았던 경우도 존재하여 정확하게 조사가 되지 않았을 가능성이 있다. 마지막으로 IONM 시스템이 도입되기 전, 신경자극기를 사용하여 수술 중 신경을 안전하게 보존한 경우는 수술 기록지에 기록하지 않아 IONM의 효용성에 대 해 정확하게 평가하기 어려운 한계가 있다. 본 연구에서 통계 적으로 의미가 없다고 하여 중요성이 낮다는 것이 아니라 모 든 변수들을 고려하여 수술에 최선을 다해야 할 것이며, 특히 수술을 집도하는 술자의 경우 더욱 경험을 쌓고 숙련도를 높 이는 데 노력을 기울여야 할 것이다.

결론적으로 갑상선 수술 중 발생하는 의인성 반회후두신경 손상은 다양한 요인들이 작용하며, 위험인자를 정확히 알고 있어야 수술 중 신경을 안전하게 보존할 수 있다. 본 연구에서 는 의인성으로 발생한 신경 마비가 전체 $0.76 \%$, 일시적인 신 경 마비는 $0.58 \%$ 로 낮게 발생하였다. 특히 영구적인 신경 마 비는 $0.18 \%$ 로 다른 보고에 비해 매우 낮게 발생하였다는 것 이 큰 의의다. 또한, 술자의 경험이 풍부할수록 영구적인 신경 마비의 발생 위험도가 감소하는 것으로 나왔으며, 따라서 비 숙련자일 경우 많은 수련을 통해 경험을 쌓아 신경을 안전하 게 보존할 수 있도록 노력해야 할 것이다.

\section{Acknowledgments}

None.

\section{Author Contribution}

Conceptualization: Kang Dae Lee, Hyoung Shin Lee, Yeong Wook Jeong. Data curation: all authors. Formal analysis: Kang Dae Lee, Sung Won Kim, Hyoung Shin Lee, Yeong Wook Jeong. Investigation: Yeong Wook Jeong, Young Seok Han. Methodology: Kang Dae Lee, Sung Won Kim, Hyoung Shin Lee, Yeong Wook Jeong. Project administration: Kang Dae Lee, Sung Won Kim, Hyoung Shin Lee. Resources: Kang Dae Lee, Sung Won Kim, Hyoung Shin Lee. Software: Yeong Wook Jeong, Young Seok Han. Supervision: Kang Dae Lee, Sung Won Kim, Hyoung Shin Lee. Validation: Kang Dae Lee, Hyoung Shin Lee. Visualization: Kang Dae Lee, Hyoung Shin Lee. Writing — original draft: Yeong Wook Jeong. Writingreview \& editing: Kang Dae Lee.

\section{ORCID}

Kang Dae Lee https://orcid.org/0000-0003-3143-1180

\section{REFERENCES}

1) Tae K, Lee HS, Jeong YG, Kim KT, Lee SH, Park YS, et al. Hypocalcemia and recurrent laryngeal nerve injury after thyroid surgery. Korean J Otolaryngol 2002;45(11):1092-7.

2) Zakaria HM, Al Awad NA, Al Kreedes AS, Al-Mulhim AM, AlSharway MA, Hadi MA, et al. Recurrent laryngeal nerve injury in thyroid surgery. Oman Med J 2011;26(1):34-8.

3) Zheng S, Xu Z, Wei Y, Zeng M, He J. Effect of intraoperative neuromonitoring on recurrent laryngeal nerve palsy rates after thyroid surgery--a meta-analysis. J Formos Med Assoc 2013;112(8): 463-72.

4) Chiang FY, Lee KW, Chen HC, Chen HY, Lu IC, Kuo WR, et al. Standardization of intraoperative neuromonitoring of recurrent laryngeal nerve in thyroid operation. World J Surg 2010;34(2):223-9.

5) Randolph GW, Dralle H; International Intraoperative Monitoring Study Group, Abdullah H, Barczynski M, Bellantone R, et al. Electrophysiologic recurrent laryngeal nerve monitoring during thyroid and parathyroid surgery: International standards guideline statement. Laryngoscope 2011;121 Suppl 1:S1-16.

6) Zhao Y, Li C, Zhang D, Zhou L, Liu X, Li S, et al. Experimental study of needle recording electrodes placed on the thyroid cartilage for neuromonitoring during thyroid surgery. Br J Surg 2019;106(3): 245-54.

7) Lee HS, Oh J, Kim SW, Jeong YW, Wu CW, Chiang FY, et al. Intraoperative neuromonitoring of recurrent laryngeal nerve during thyroidectomy with adhesive skin electrodes. World J Surg 2020;44(1):148-54.

8) Godballe C, Madsen AR, Sørensen CH, Schytte S, Trolle W, HelwegLarsen J, et al. Risk factors for recurrent nerve palsy after thyroid surgery: A national study of patients treated at Danish departments of ENT head and neck surgery. Eur Arch Otorhinolaryngol 2014; 271(8):2267-76.

9) Lee YS, Nam KH, Chung WY, Chang HS, Park CS. Postoperative complications of thyroid cancer in a single center experience. $\mathrm{J}$ Korean Med Sci 2010;25(4):541-5.

10) Bergenfelz A, Jansson S, Kristoffersson A, Mårtensson H, Reihnér E, Wallin G, et al. Complications to thyroid surgery: Results as reported in a database from a multicenter audit comprising 3,660 patients. Langenbecks Arch Surg 2008;393(5):667-73.

11) Higgins TS, Gupta R, Ketcham AS, Sataloff RT, Wadsworth JT, Sinacori JT. Recurrent laryngeal nerve monitoring versus identification alone on post-thyroidectomy true vocal fold palsy: a meta-analysis. Laryngoscope 2011;121(5):1009-17.

12) Dionigi G, Boni L, Rovera F, Rausei S, Castelnuovo P, Dionigi R. Postoperative laryngoscopy in thyroid surgery: Proper timing to detect recurrent laryngeal nerve injury. Langenbecks Arch Surg 
2010;395(4):327-31

13) Han YJ, Lee KD, Kim SW, Kim WS, Cha YW, Lee JH, et al. Iatrogenic injury of recurrent laryngeal nerve during thyroid surgery. J Korean Thyroid Assoc 2009;2(2):128-34.

14) Iqbal $M$, Parveen S. Recurrent laryngeal nerve palsy and hypocalcemia with and without bilateral ligation of inferior thyroid artery in total thyroidectomy. J Surg Pakistan (International) 2015;20(1):19-22.

15) Misiolek M, Waler J, Namyslowski G, Kucharzewski M, Podwinski A, Czecior E. Recurrent laryngeal nerve palsy after thyroid cancer surgery: A laryngological and surgical problem. Eur Arch Otorhinolaryngol 2001;258(9):460-2.

16) Kasemsuwan L, Nubthuenetr S. Recurrent laryngeal nerve paralysis:
A complication of thyroidectomy. J Otolaryngol 1997;26(6):365-7.

17) Jiang Y, Gao B, Zhang X, Zhao J, Chen J, Zhang S, et al. Prevention and treatment of recurrent laryngeal nerve injury in thyroid surgery. Int J Clin Exp Med 2014;7(1):101-7.

18) Chen HC, Pei YC, Fang TJ. Risk factors for thyroid surgery-related unilateral vocal fold paralysis. Laryngoscope 2019;129(1):275-83.

19) Liu MY, Chang CP, Hung CL, Hung CJ, Huang SM. Traction injury of recurrent laryngeal nerve during thyroidectomy. World J Surg 2020;44(2):402-7.

20) Prokopakis E, Kaprana A, Velegrakis S, Panagiotaki I, Chatzakis $\mathrm{N}$, Iro $\mathrm{H}$, et al. Intraoperative recurrent laryngeal nerve monitoring in revision thyroidectomy. Eur Arch Otorhinolaryngol 2013;270(9): 2521-4. 